\title{
Evaluation of Time in Therapeutic Range in Patients with Cerebrovascular Disease Receiving Treatment with Warfarin
}

\author{
(iD) Neslihan Eşkut ${ }^{1}$, (iD) Pınar Tamer ${ }^{1}$, (iD) Özge Yılmaz Küsbeci², (iD) Ceyla Ataç${ }^{1}$, (iD) Ijpek Inci ${ }^{1}$ \\ ${ }^{1}$ M.D. Spec., University of Health Sciences, İzmir Bozyaka Training and Research Hospital, Department of Neurology, İzmir \\ Turkey \\ ${ }^{2}$ Prof. Dr., İzmir Economy University Medical Park Hospital, Department of Neurology, İzmir, Turkey.
}

Öz

Varfarin Tedavisi Alan Serebrovasküler Hastalı̆̆ı Olan Hastalarda Terapötik Aralıkta Olma Oranlarının Değerlendirilmesi

Amaç: Varfarin tedavisinin etkinliği, Terapötik Aralıkta Olma Zamanı (TTR) ile doğrudan ilișkilidir. Bu çalıșmada, inme polikliniğinde izlenen warfarin kullanan hastalarda etkinlik ve hedefe ulaşma oranlarının belirlenmesi amaçlanmıştır.

Yöntem: İnme polikliniğinde izlenen, varfarin kullanan 103 hasta, retrospektif olarak değerlendirildi. Varfarin kullanım süreleri, ve endikasyonlarıyla trombotik veya hemorajik komplikasyonları kaydedildi. Hedef INR değeri mekanik kapaklı hastalarda 3.0-3.5, diğer endikasyonlar için 2.0-3.0 arasında belirlendi.

Bulgular: Çalıșmaya 47'si erkek 56’sı kadın olmak üzere, ortalama yașları $67.14 \pm 14.19$ olan 103 hasta dahil edildi.Varfarin kullanım endikasyonları sırasıyla hastaların \%61,6'sında non-valvular atrial fibrilasyon, \%12.62'sinde eko kardiyografide (EK0) akinetik/hipokinetik alan, \%8.74'ünde trombofili, \%3.88'inde metalik protez kapak, \%6.79'unda sık geçici iskemik ataklar, \%5.82'sinde atrial fibrilasyonla birlikte EKO'da hipokinetik alan ve \% 0.87'sinde vertebral arter diseksiyonuydu. Hastaların \%46.8'inin iyi kontrolde olduğu, ortalama TTR'nin \%64.09 olduğu saptandı; ayrıca, TTR \%36.8'inde \%100 idi. Ikisinde intraserebral kanama olan 10 hastada (\%9.70) minör/majör hemorajik olay kaydedildi.

Sonuç: Bu çalıșmada saptanan ortalama TTR değeri, ülkemizde bildirilen orandan oldukça yüksektir. Çalıșma bulgularımız, yakın izlemin inmeli hastalarda çok önemli ve hayati olduğunu göstermektedir. Varfarin kullanan inme hastalarının düzenli takibinin ve hastaları bilgilendirmenin optimal antikoagülasyon sağlanmasına ve komplikasyonları önlemeye yardımcı olacağına kanısındayız.

Anahtar Kelimeler: Varfarin, İskemik Serebrovasküler Hastalık, Antikoagulasyon, Etkinlik

\section{Abstract}

\section{Evaluation of Time in Therapeutic Range in Patients with Cerebrovascular Disease Receiving Treatment with Warfarin}

Objective: The efficacy of warfarin therapy correlates with the Time in Therapeutic Range (TTR). This study aimed to investigate the efficacy and target achievement rates in patients using warfarin who were followed up in stroke outpatient clinics.

Methods: In this study, 103 patients who had been under warfarin treatment were retrospectively evaluated. Duration and indications for warfarin use, thrombotic or hemorrhagic complications were recorded. Target INR value was 3.0-3.5 in patients with mechanical valves and 2.0-3.0 in those using warfarin for other indications.

Results: In this study, 103 patients with a mean age of 67.14 $14.19,47$ men and 56 women, were included. Indications for warfarin use, respectively, were non-valvular atrial fibrillation (AF) in 61.6\% of the patients, akinetic/hypokinetic segment on echocardiography (ECH0) in $12.62 \%$, thrombophilia in $8.74 \%$, metallic prosthetic valve in 3.88\%, frequent transient ischemic attacks in $6.79 \%$, a hypokinetic segment on ECHO with atrial fibrillation in $5.82 \%$ and vertebral artery dissection in $0.87 \% .46 .8 \%$ of the patients were determined to be in good control, with a mean TTR of 64.09\%; also, TTR was $100 \%$ in 36.8\% of them. Minor/major hemorrhagic event was noted in 10 patients (9.70\%), two of whom had an intracerebral hemorrhage.

Conclusion: The mean TTR value detected in this study is considerably higher than the rate reported in our country. Findings of this study suggest that close monitoring is paramount of importance and vital in patients with stroke. Regular monitoring of stroke patients using warfarin will be beneficial in terms of informing patients, providing optimal anticoagulation and preventing complications.

Keywords: Warfarin, Ischemic Cerebrovascular Disease, Anticoagulation, Efficacy

Nasıl Atıf Yapmalı / How to Cite: Eșkut N, Tamer P, Küsbeci ÖY, Ataç C, Inci I. Evaluation of Time in Therapeutic Range (TTR) in Patients with Cerebrovascular Disease Receiving Treatment with Warfarin. MKÜ Tıp Dergisi. 2021;12(43):88-93. https://doi.org/10.17944/mkutfd.937769

Sorumlu Yazar/Corresponding Author: M.D. Spec., Neslihan Eșkut

Email: nespur@hotmail.com

ORCID iD: 0000-0003-1882-8992 


\section{INTRODUCTION}

Ischemic stroke is one of the diseases that may cause high mortality and morbidity worldwide. In the acute phase of stroke, appropriate treatment can be determined for secondary prevention by revealing etiological reasons (1). Cardioembolic strokes (CE) have accounted for approximately $20-40 \%$ of all strokes, with arterial dissections being one of the common etiological causes in young stroke patients $(2,3)$. In the medical treatment of arterial dissection, in which impairment of arterial wall integrity, intramural thrombus development causes transient ischemic attack or ischemic cerebrovascular disease, anticoagulation has been among the treatment options despite no consensus exists (4). Although cerebral venous thrombosis (CVT) is a rare cause of stroke, it should definitely be considered in young stroke etiology (5). Etiological factors should be investigated in detail in patients diagnosed with SVT. In the presence of prothrombotic genetic features that predispose to recurrent CVT, long-term anticoagulation should ideally be planned (6).

Warfarin is widely used in primary and secondary prevention from thromboembolic events. Warfarin, a vitamin $\mathrm{K}$ antagonist, has a narrow therapeutic window (7). Regular monitoring is required for warfarin users due to the high prevalence of drug-drug interactions, interaction with food and alcohol, liver cytochrome p450 enzyme, and pharmacokinetic-pharmacodynamic properties may differ individually (8-10).

In patients scheduled for anticoagulation, it is also essential to use and follow up at the appropriate dose as choosing the right treatment. Safe and effective use of warfarin without standard dosing can be provided by monitoring the 'International Normalized Ratio (INR)' value. Exceeding target INR value may lead to hemorrhagic complications; not being reached may lead to thromboembolic complications $(11,12)$. 'Time in therapeutic range' (TTR), a relatively new concept, which expresses the quality of anticoagulation, denotes the percentage of residence time at the target INR value of patients using warfarin $(11,13)$.

This study aimed to investigate TTR in patients receiving warfarin therapy for different reasons, followed in our stroke outpatient clinic, and to assess their complications during follow-up.

\section{METHOD}

This retrospective study included 103 patients aged 18 and over who had been under warfarin treatment. Patients who had at least five INR measurements, followed up in stroke outpatient clinic at the University of Health Sciences, Izmir Bozyaka Training and Research Hospital, between March 2017 and August 2017 evaluated. A total of 13 patients who had been using warfarin for less than three months, who had less than five INR measurements between the specified dates, whose warfarin treatment was temporarily discontinued due to tooth extraction and operation preparation, were excluded. Those with INR measurement intervals less than one week were also excluded not to cause TTR calculation errors. Demographic data, duration of warfarin use, comorbid diseases, indications for warfarin use, drugs that patients used alongside warfarin, and thrombotic or hemorrhagic complications were scanned from the hospital information system and patient files and recorded; then statistically analyzed. HAS-BLED (Hypertension, abnormal kidney/liver function, stroke, bleeding history, labile INR, advanced age [> 65], and concomitant drug use) score was computed to determine the risk of bleeding, particularly minor/major bleeding complications. The distribution of HAS-BLED scoring, ranging from 1 to 5 , among patients with or without minör/major bleeding was evaluated. Target INR value was identified between 3.0-3.5 in patients with mechanical valves and 2.0-3.0 in those using warfarin for other indications. TTR was calculated using the Rosendaal method (13). According to the TTR; subjects were classified as in poor (if TTR <\%50), moderate (if TTR \%50-70), and good (if TTR > \%70) anticoagulation control.

Table 1. Demographic characteristics and comorbid diseases of the study patients

\begin{tabular}{|l|c|c|}
\hline Age (years) & mean \pm SD & $\begin{array}{c}\text { minimum- } \\
\text { maximum }\end{array}$ \\
\hline & median & $\begin{array}{c}18-90 \\
\text { minimum- } \\
\text { maximum }\end{array}$ \\
\hline $\begin{array}{l}\text { Duration of warfarin use } \\
\text { (years) }\end{array}$ & 34.48 & $3-240$ \\
\hline & $\mathbf{n}$ & $\%$ \\
\hline Female/Male & $56 / 47$ & $54,37 / 45,63$ \\
\hline Hypertension & 51 & 45.91 \\
\hline Diabetes mellitus & 22 & 21.35 \\
\hline Hyperlipidemia & 23 & 22.33 \\
\hline Congestive heart failure & 9 & 8.73 \\
\hline Coronary artery disease & 17 & 16.50 \\
\hline History of stroke/TIA & 11 & 10.67 \\
\hline TIA: Transient ischemic attack & & \\
\hline
\end{tabular}

\section{Statistical analysis}

Statistical analysis of obtained data was performed using the SPSS 21.0 package program (IBM Corp.; Armonk, NY, USA). Continuous variables that fit the normal distribution were 
specified as the mean \pm standard deviation and continuous variables that did not conform to the normal distribution as the median (min-max). Categorical variables were expressed as percentages.

\section{Table 2. Distribution of indications for study patients' warfarin use}

\begin{tabular}{|l|c|c|}
\multicolumn{1}{|c|}{ Disease as a cause of indication } & n & $\%$ \\
\hline Non-valvular AF only & 63 & 61.16 \\
\hline Isolated akinesia/hypokinesia in the left ventricle & 13 & 12.62 \\
\hline $\begin{array}{l}\text { Akinesia/hypokinesia in the left ventricle + non- } \\
\text { valvular AF }\end{array}$ & 7 & 6.79 \\
\hline Transient ischemic attack & 7 & 6.79 \\
\hline Prosthetic valve disease & 4 & 3.88 \\
\hline Genetic prothrombotic risk factor & 9 & 8.74 \\
\hline Intraatrial thrombus & 1 & 0.97 \\
\hline Vertebral artery dissection & 1 & 0.97 \\
\hline AF:
\end{tabular}

AF: atrial fibrillation

\section{RESULT}

In this study, 103 patients, 47 men and 56 women, were included. The mean age of the patients was 67.14 \pm 14.19 . The median duration of warfarin use was 30 (min-max: 3-240) months. The most common comorbid diseases of the patients were hypertension (45.91\%) and diabetes mellitus (DM) (21.35\%). The demographic characteristics and comorbid diseases of the study patients are given in Table 1.

Indications for warfarin use, respectively, were non-valvular atrial fibrillation (AF) in $61.6 \%$ of the subjects, akinetic/ hypokinetic segment on echocardiography (ECHO) in 12.62\%, thrombophilia, in $8.74 \%$, metallic prosthetic valve in $3.88 \%$, frequent transient ischemic attacks in $6.79 \%$, and a hypokinetic segment on ECHO with atrial fibrillation in \%5.82. Vertebral artery dissection was detected only in one patient (Table 2). The distribution of indications for study patients' warfarin use is presented in Table 2.

Considering TTR, $46.8 \%$ of the patients were in good control, $33 \%$ in moderate, and $20.38 \%$ were in poor control, with a mean TTR of $64.09 \%$. Also, TTR was $100 \%$ and $>\% 70$ in $36.8 \%$ and $55.3 \%$ of the subjects, respectively. No recurrent thrombotic or thromboembolic event was observed during follow-up. Minor/major hemorrhagic event was noted in 10 patients (9.70\%), two of whom had an intracerebral hemorrhage (Table 3). The HAS-BLED score was 3 and above in $55.33 \%$ of the patients. Table 3 presents the distribution of HAS-BLED scoring (ranging from 1 to 5) among patients with and without minor/major bleeding complications.
Only four patients had no comorbidity or use of drugs other than warfarin. ARB/ACE inhibitör (n:37 (35.9\%)) was the most commonly used drug other than warfarin, followed by statin (n:28 (27.18\%)), beta-blocker (n:28 (27.18\%)), and calcium channel blocker (n:21 (20.38\%)) (Table 4). The distribution of drugs that patients used alongside warfarin is shown in Table 4.

Table 3. Distribution of HAS-BLED scoring among patients

\begin{tabular}{|c|c|c|c|c|}
\hline & \multicolumn{2}{|c|}{$\begin{array}{c}\text { Patients with minor/ } \\
\text { major bleeding } \\
\text { complications }\end{array}$} & \multicolumn{2}{|c|}{$\begin{array}{c}\text { Patients without } \\
\text { minor/major bleeding } \\
\text { complications }\end{array}$} \\
\hline $\begin{array}{c}\text { HAS-BLED } \\
\text { SCORE }\end{array}$ & $\mathbf{n}$ & $\%$ & $\mathbf{n}$ & $\%$ \\
\hline 1 & 0 & 0.0 & 21 & 22.8 \\
\hline 2 & 2 & 20.0 & 22 & 23.9 \\
\hline 3 & 4 & 40.0 & 34 & 37.0 \\
\hline 4 & 4 & 40.0 & 12 & 13.0 \\
\hline 5 & 0 & 0.0 & 3 & 3.3 \\
\hline
\end{tabular}

HAS-BLED: Hypertension, Abnormal renal/liver function, Stroke, Bleeding history or predisposition, Labile international normalized ratio

\section{DISCUSSION}

PPeople with CE stroke constitute the majority of the patients who have been followed up in the stroke clinic and using warfarin. The cardioembolic ischemic stroke has been reported to develop secondary to $50 \% \mathrm{AF}, 20 \%$ cardiac thrombus, and 15\% valvular diseases (2). Cardiac etiologies are categorized in terms of embolism recurrence as low, medium, and high risk.AF/Atrial flutter, left atrial/ventricular thrombus, congestive heart failure, prosthetic valve presence, and chronic myocardial infarction, along with ejection fraction below $28 \%$, carries a high CE risk $(1,14)$. In the present study, the patients most frequently evaluated in the high CE risk group were patients with non-valvular AF (61.6\%), followed by those with akinetic hypokinetic segment secondary to myocardial infarction(12.62\%). The others were ranked as follows: those with AF and hypokinetic segment (6.79\%), intraatrial thrombus (0.97\%), and mechanical heart valve (3.88\%). Other warfarin indications of this study were the presence of previous CVT and underlying genetic prothrombotic factors in 10 patients, of whom prothrombin C mutation was detected 
in three patients, prothrombin S deficiency in three patients, and homozygous methylenetetrahydrofolate reductase (MTHFR) mutation in four patients. Besides, one patient's reason for using warfarin was vertebral artery dissection.

With TTR, which has been used to show the percentage of time residence within the targeted INR range, anticoagulation control gets revised (15). In this formula, it has been assumed that INR varies linearly between measurements; also, INR values are interpolated on the days between measurements (13). Evaluating TTR allows physicians to predict warfarin therapy's success because TTR is a crucial determinant of warfarin efficacy and safety (16). Farsat et al.s' study revealed that the mean TTR was calculated as $54.9 \%$, and $37.3 \%$ of the patients were in good warfarin control, $24.6 \%$ in intermediate, and $38.1 \%$ in poor control (15). With the launch of new oral anticoagulants in recent years, extensive controlled clinical trials investigating optimal anticoagulation efficacy have been performed. The mean TTR was reported as 55.2\% (63\% in Northern Europe, $64 \%$ in North America) in the ROCKET-AF study, $66 \%$ in the ARISTOTLE study $(17,18)$. In a study in which 6250 patients from four European countries were evaluated, the rate of patients using warfarin to be in good control was reported as $47.8 \%, 44.2 \%, 46.1 \%$ ve $65.4 \%$ for patient groups of France, Germany, Italy, and the UK, respectively (19). Although the proportion of our patients in good control is below the UK patient group's values emphasized in the study mentioned above, it is similar to that in other countries. Also, It is important to note that the mean TTR in this study is higher than that in Farsad et al.'s study, while it is close to ROCKET-AF Northern Europe, North America values (15,1719).

The most comprehensive study conducted in Turkey, the VARFARIN-TR study, where 4987 patients from 42 centers and 24 cities were included, showed for the first time that the mean TTR was statistically significantly different between geographical regions, and this difference was an independent risk factor for TTR. Besides, while the mean TTR was reported to be $49.5 \%$, it appeared to be higher in the Aegean and Marmara regions than other regions (54.99\% and 54.65\%) (20). In this study from a tertiary level hospital in Izmir, we see that the mean TTR tends to be higher than that of the geographical regions in the VARFARIN-TR study and is similar to the Aegean region mean. Despite the widespread use of warfarin, prior publications have also pointed out that time passing in the effective interval between countries and regions is significantly different $(17,21,22)$. Again, in the WATER (Warfarin in Therapeutic Range) study from Turkey, the mean TTR was expressed as being low (41.3\%) (23). Emphasizing that hypertension, coronary artery disease, congestive heart failure, and smoking were associated with low TTR, the Warfarin-TR study suggested that the drugs used in these diseases might affect
TTR. Based on this, the high rates of these diseases in Turkish society and patients who do not know enough about warfarin therapy have been thought to cause low TTR (20). In this study, all patients except four had comorbid diseases and drugs they used alongside warfarin (Table 4).

In contrast, Karaçağlar et al.'s study in 202 patients with non-valvular AF, who used warfarin, concluded TTR as 83.5\%, considerably higher than other studies (24). Evaluating patients' one-year INR follow-up in their studies, Kılıç et al. also revealed significantly higher TTR in patients who were followed up in stroke outpatient clinic than in those followed up in a general outpatient clinic. It is more tempting to consider that providing follow-up of INR in private branch outpatient clinics by individual physicians brings the advantages of more frequent reminders about drug-food interaction, and fewer missed INR controls and closer monitoring of disease status (21).

There is also a fine line in patients using warfarin, with a narrow therapeutic window, between bleeding-related complications and stroke risk (20). Low TTR, use of nonsteroidal anti-inflammatory drugs, high bleeding risk score, and combined use of warfarin and acetylsalicylic acid have been established to be associated with both minor and major hemorrhagic complications $(20,21)$. While no recurrent ischemic thrombotic event was found in this study, complications, such as intracerebral bleeding in two patients and nose bleed, bleeding gums and hematuria in eight patients were observed. Eight of these ten patients had a HAS-BLED score of $\geq 3,6$ had low TTR $(<50 \%)$; one of the two patients who developed intracerebral bleeding was using warfarin acetylsalicylic acid in combination.

This study evaluated patients' anticoagulation efficacy using warfarin followed up in our stroke outpatient clinic; the mean TTR was $64.09 \%$; TTR was $100 \%$ in about one in three patients. On the other hand, TTR $<50 \%$ showed patients were in poor control and determined in $20.38 \%$ of patients. Therefore, other drugs they were using, which can affect the INR value of them determined to be under poor control, were revised. Two patients' antiepileptic treatment, of whom were with concomitant use of liver enzyme-inducing antiepileptic drugs, were modified. Five patients were consulted with a cardiologist in the follow-up, and their treatments changed with new oral anticoagulant drugs. Considering all these findings, education of patients and their relatives, review of drugs used in addition to warfarin, and regular follow-up of patients are essential in providing more effective and successful anticoagulation. Moreover, based on previously published literature, it has been shown that there is an inverse correlation between higher TTR values and ischemic complications and mortality $(25,26)$. 
Our single-center study's main limitations, where we evaluated the treatment efficacy with TTR in patients with ischemic cerebrovascular disease using warfarin due to different etiologies, are the small number of patients included in the retrospective setup of this research.

Table 4. Distribution of drugs that patients used alongside warfarin

\begin{tabular}{|l|c|c|}
\hline \multicolumn{1}{|c|}{ Drug } & n & \% \\
\hline ARB/ACE inhibitor & 37 & 35.9 \\
\hline Antidiabetic therapy & 16 & 15.53 \\
\hline Calcium channel blocker & 21 & 20.38 \\
\hline Beta-blocker & 28 & 27.18 \\
\hline Statin & 28 & 27.18 \\
\hline Diuretic & 9 & 8.73 \\
\hline Digoxin & 2 & 1.94 \\
\hline Antiaggregant treatment & 5 & 4.85 \\
\hline AR: Angotensin
\end{tabular}

ARB: Angiotensin receptor blocker; ACE inhibitor: Angiotensinconverting enzyme inhibitor

\section{CONCLUSIONS}

The mean TTR higher than most of the study results that emerged from various publications in our country has revealed the significance of regular outpatient clinic follow-up, patient compliance, and the importance of informing patients and their relatives about treatment. We believe that measuring the level of knowledge and correcting the deficiencies during the follow-up of patients using warfarin will help provide optimal anticoagulation. In this context, the findings obtained in this study suggest that TTR assessment can be a predictor for physicians. However, we should note that these results should be interpreted with caution and enlightened with further studies, shedding light on this topic.

\section{ACKNOWLEDGEMENT}

Peer-Review

Externally Peer Reviewed

Conflict of Interest

The authors declare that they have no conflict of interests regarding content of this article.

Financial Support

The Authors report no financial support regarding content of this article.

Ethical Declaration

Ethical approval was obtained from University of Health Sciences, Izmir Bozyaka Training and Research Hospital.Clinical Research Ethical Committee with date 27/11/2020 and number 09, and Helsinki Declaration rules were followed to conduct this study.

\section{REFERENCES}

1. Sacco RL, Adams R, Albers G, et al.; AHA; American Stroke Association Council on Stroke; Council on Cardiovascular Radiology and Intervention; American Academy of Neurology. Guidelines for prevention of stroke in patients with ischemic stroke or transient ischemic attack. Stroke. 2006;37(2):577617. https://doi.org/10.1161/01.STR.0000199147.30016.74.

2. Palacio S, Hart RG. Neurologic manifestations of cardiogenic embolism: an update. Neurol Clin. 2002;20(1):179-193, vii. https://doi.org/10.1016/s0733-8619(03)00058-6.

3. Schievink WI, Mokri B, O'Fallon WM. Recurrent spontaneous cervical-artery dissection. N Engl J Med. 1994;330(6):393-397. https://doi.org/10.1056/NEJM199402103300604.

4. Kasner SE. CADISS: a feasibility trial that answered its question. Lancet Neurol. 2015;14(4):342-343. https://doi.org/10.1016/ S1474-4422(14)70271-6.

5. Ferro JM, Canhão P, Bousser MG, et al; ISCVT Investigators. Cerebral vein and dural sinus thrombosis in elderly patients. Stroke. 2005;36(9):1927-1932. https://doi.org/10.1161/01. STR.0000177894.05495.54.

6. Ferro JM, Canhão P, Stam J, et al; ISCVT Investigators. Prognosis of cerebral vein and dural sinus thrombosis: results of the International Study on Cerebral Vein and Dural Sinus Thrombosis (ISCVT). Stroke. 2004;35(3):664-670. https://doi. org/10.1161/01.STR.0000117571.76197.26.

7. Natarajan S, Ponde CK, Rajani RM, et al. Effect of CYP2C9 and VKORC1 genetic variations on warfarin dose requirements in Indian patients. Pharmacol Rep. 2013;65(5):1375-1382. https://doi.org/10.1016/s1734-1140(13)71496-8.

8. Joffe $\mathrm{HV}, \mathrm{Xu} \mathrm{R}$, Johnson $\mathrm{FB}$, et al. Warfarin dosing and cytochrome P450 2C9 polymorphisms. Thromb Haemost. 2004;91(6):1123-1128. https://doi.org/10.1160/TH04-02-0083.

9. Holbrook AM, Pereira JA, Labiris R, et al. Systematic overview of warfarin and its drug and food interactions. Arch Intern Med. 2005;165(10):1095-1106. https://doi.org/10.1001/ archinte.165.10.1095

10. Ansell J, Hirsh J, Hylek E, et al. Pharmacology and management of the vitamin $\mathrm{K}$ antagonists: American College of Chest Physicians Evidence-Based Clinical Practice Guidelines (8th Edition). Chest. 2008;133(6):160S-198S. https://doi. org/10.1378/chest.08-0670. P

11. Caldeira D, Cruz I, Morgado G, et al. Evaluation of time in therapeutic range in anticoagulated patients: a single-center, retrospective, observational study. BMC Res Notes. 2014;7:891. https://doi.org/10.1186/1756-0500-7-891.

12. Odén A, Fahlén M, Hart RG. Optimal INR for prevention of stroke and death in atrial fibrillation: a critical appraisal Thromb Res. 2006;117(5):493-499. https://doi.org/10.1016/j. thromres.2004.11.025. 
13. Rosendaal FR, Cannegieter SC, van der Meer FJ, Briët E. A method to determine the optimal intensity of oral anticoagulant therapy. Thromb Haemost. 1993;69(3):236-9.

14. Adams HP Jr, Bendixen BH, Kappelle LJ, et al. Classification of subtype of acute ischemic stroke. Definitions for use in a multicenter clinical trial. TOAST. Trial of Org 10172 in Acute Stroke Treatment. Stroke;24(1):35-41. https://doi. org/10.1161/01.str.24.1.35.

15. Farsad BF, Abbasinazari M, Dabagh A, Bakshandeh $\mathrm{H}$. Evaluation of Time in Therapeutic Range (TTR) in Patients with Non-Valvular Atrial Fibrillation Receiving Treatment with Warfarin in Tehran, Iran: A Cross-Sectional Study. J Clin Diagn Res. 2016;10(9):FC04-FC06. https://doi.org/10.7860/ JCDR/2016/21955.8457.

16. Schmitt L, Speckman J, Ansell J. Quality assessment of anticoagulation dose management: comparative evaluation of measures of time-in-therapeutic range. J Thromb Thrombolysis. 2003;15(3):213-216. https://doi.org/10.1023/ B:THR0.0000011377.78585.63.

17. Singer DE, Hellkamp AS, Piccini JP, et al; ROCKET AF Investigators. Impact of global geographic region on time in therapeutic range on warfarin anticoagulant therapy: data from the ROCKET AF clinical trial. J Am Heart Assoc. 2013;2(1):e000067. https://doi.org/10.1161/JAHA.112.000067.

18. Granger CB, Alexander JH, McMurray JJ, et al; ARISTOTLE Committees and Investigators. Apixaban versus warfarin in patients with atrial fibrillation. N Engl J Med. 2011 15;365(11):981-992. https://doi.org/10.1056/NEJMoa1107039.

19. Cotté FE, Benhaddi H, Duprat-Lomon I, et al. Vitamin K antagonist treatment in patients with atrial fibrillation and time in therapeutic range in four European countries. Clin Ther. 2014;36(9):1160-1168. https://doi.org/10.1016/j. clinthera.2014.07.016.

20. ÇelikA, İzciS, Kobat MA, et al; WARFARIN-TR Study Collaborates. The awareness, efficacy, safety, and time in therapeutic range of warfarin in the Turkish population: WARFARIN-TR. Anatol J Cardiol. 2016;16(8):595-600. https://doi.org/10.5152/ AnatolJCardiol.2015.6474.
21. Kılıç S, Çelik A, Çakmak HA, et al. The Time in Therapeutic Range and Bleeding Complications of Warfarin in Different Geographic Regions of Turkey: A Subgroup Analysis of WARFARIN-TR Study. Balkan Med J. 2017;34(4):349-355. https://doi.org/10.4274/balkanmedj.2016.1617.

22. Pengo V, Pegoraro C, Cucchini U, Iliceto S. Worldwide management of oral anticoagulant therapy: the ISAM study. J Thromb Thrombolysis. 2006;21(1):73-77. https://doi. org/10.1007/s11239-006-5580-y.

23. Ertaş F, Kaya H, Kaya Z, et al. Epidemiology of atrial fibrillation in Turkey: preliminary results of the multicenter AFTER study. Turk Kardiyol Dern Ars. 2013;41(2):99-104. https://doi. org/10.5543/tkda.2013.18488.

24. Karaçağlar E, Atar I, Yetiş B, et al. Atriyal fibrilasyon hastalarında emboli risk faktörleri sıklığı ve emboli önleyici tedavilerin uygunluğunun araștırılması: Tek üçüncül bir merkez deneyimi. Anadolu Kardiyol Derg. 2012;12(5):384-90. https://doi.org/10.5152/akd.2012.123.

25. Wan Y, Heneghan C, Perera R, et al. Anticoagulation control and prediction of adverse events in patients with atrial fibrillation: a systematic review. Circ Cardiovasc Qual Outcomes. 2008 ;1(2):84-91. https://doi.org/10.1161/ CIRCOUTCOMES.108.796185.

26. Connolly SJ, Pogue J, Eikelboom J, et al; ACTIVE W Investigators. Benefit of oral anticoagulant over antiplatelet therapy in atrial fibrillation depends on the quality of international normalized ratio control achieved by centers and countries as measured by time in therapeutic range. Circulation. 2008;118(20):20292037. https://doi.org/10.1161/CIRCULATIONAHA.107.750000. 